\title{
The Effect of Environmental Disclosure and Performance on Profitability in the Companies Listed on the Stock Exchange of Thailand (SET)
}

\author{
Indah Fajarini Sri Wahyuningrum¹, Muhammad Ihlashul Amal¹, and Suci Sularsih ${ }^{1}$
}

${ }^{1}$ Accounting Department, Universitas Negeri Semarang; e-mail: $\underline{\text { i.fajarini@mail.unnes.ac.id }}$

\begin{abstract}
The main objective of this study is to determine the empirical evidence of the effect of environmental disclosure, environmental performance, company age, and company size on profitability. The purposive sampling method was used to determine the sample of companies and obtained 85 companies from a total population of 100 large companies listed on the Thailand Stock Exchange (SET) in 2018. The data analysis technique used was multiple linear regression analysis using analysis tool IBM SPSS Statistics version 26. The results of this study prove that environmental disclosure has a significant positive effect on profitability. Environmental performance and company size have a significant negative effect on profitability. On the other hand, company age is not proven to have a significant effect on profitability. Based on the research results, it can be concluded that more extensive environmental disclosure is able to increase the achievement of profitability. However, company age is not a factor affecting profitability. Meanwhile, company size and environmental performance as measured by total assets and the existence of ISO 14001 certifications are proven to reduce the level of company profitability. This study also has several limitations, including the time period which is limited to only one time period, namely 2018. It is expected that further studies can expand the time period by more than one year. This is since using a time period of more than one year can illustrate the effect of environmental disclosure and environmental performance, company age and company size on the profitability achieved by the companies. In addition, it is expected that the results of this study can provide input to companies to be more concerned regarding company performance activities, especially on the environment because there are still many companies that have low levels of environmental disclosure even though environmental disclosure in Thailand is still voluntary.
\end{abstract}

Keywords: Environmental disclosure, Environmental performance, Company age, Company size, Profitability, Thailand

Citation: Wahyuningrum, I. F. S., Amal, M. I., and Sularsih, S. (2021). The Effect of Environmental Disclosure and Performance on Profitability in the Companies Listed at Stock Exchange of Thailand (SET). Jurnal Ilmu Lingkungan, 19(1), 66-72, doi:10.14710/jil.19.1.66-72

\section{Introduction}

Profitability is one of the important keys that determine the sustainability of a company. High profitability triggers the interest of stakeholders to continue investing. This is since the achievement of high profitability indicates high performance as well. Indirectly, this condition is able to improve the welfare of stakeholders through a high rate of return that will be received later. Profitability is also one of the main pillars for the company to be able to survive in the long-term (Alarussi \& Alhaderi, 2018). Companies that generate high profits indicate that the companies have a healthy financial performance (Yanto \& Muzzammil, 2016).

The companies in Thailand that become the research samples were the companies with the largest market capitalization in SET100 with an average market capitalization of the SET100 index in 2018 of 13,15 trillion baht. High corporate profitability is directly proportional to complex corporate activities. This situation has had various positive impacts, such as the availability of wider job opportunities which affects the level of community welfare, increased regional income, and so on. However, corporate operational activities which were increasingly complex, not only had some positive impacts but also had negative impacts, such as the environmental conditions which were getting worse around the company. Thailand becomes one of the countries facing various environmental problems, which arise due to corporate operational activities.

Bangkok was back covered in hazardous dust particles which started from 2017 to 2019. Based on the Guidelines of the World Health Organization (WHO), the annual level of particulate matter (PM) 2,5 is not more than 10 micrograms, but in 2018, PM 2,5 levels in Bangkok city reached 135 micrograms per m3 (Christiastuti, 2018). At the beginning of 2019, based on the data from World Air Quality Index project (AQICN), Air Quality Index (AQI) of Bangkok was in the range of 170 and was included in the category of unhealthy numbers. Some of the causes of this pollution included factory pollution, construction work, traffic fumes, and land burning (BBC Indonesia, 
Wahyuningrum, I. F. S., Amal, M. I., and Sularsih, S. (2021). The Effect of Environmental Disclosure and Performance on Profitability in the Companies Listed at Stock Exchange of Thailand (SET). Jurnal IImu Lingkungan, 19(1), 66-72, doi:10.14710/jil.19.1.66-72

2019). Factory pollution is a serious problem that is still becoming an important study in the discussion of environmental sustainability. The quantity of factory pollution is largely determined by company age and size. However, these two things cannot guarantee the extent of environmental disclosure done by a company.

Besides having an impact on health and the economy, this pollution also has an impact on the tourism industry in Thailand which is the closing of several tourism objects due to high levels of pollution. This is much unexpected considering the tourism sector in Thailand provides a sizeable contribution to the state economy. The Tourism and Sports Ministry of Thailand reported that Thailand's tourism sector contributed 17.7 percent to Thailand's gross domestic product (GDP) in 2016 and 16,7 percent in 2015 . The World Travel and Tourism Council stated that tourism accounted for 10,4 percent of global GDP and 313 million jobs, or 9,9 percent of total employment in 2017 (Khidir, 2019).

The occurrence of these various problems has prompted the creation of various regulatory changes regarding environmental disclosure obligations. This indicates the seriousness of the Thailand government in dealing with environmental problems that occur. The evolution of the Environmental, Social, and Governance (ESG) framework carried out by Thailand, among others, in 2010, Thailand issued Guidelines for Sustainability Reporting framework which was voluntary disclosure. In 2012, this framework was later changed to Principles of Good Corporate Governance, but it was still voluntary disclosure. Furthermore, in 2017, Thailand published a Corporate Governance Code framework which serves as a guideline in the implementation of corporate governance, which is mandatory disclosure (CFA Institute, 2019).

There has been a lot of research on profitability, but there are still some inconsistencies in results. As research conducted by Ningtyas \& Triyanto (2019), Che-Ahmad \& Osazuwa (2015), and Nurleli \& Faisal (2017) which prove that environmental disclosure has a significant positive effect on profitability. A different thing showed by the research of Sulistiawati \& Dirgantari (2017) and Nor et al., (2016) which show that there is no effect of environmental disclosure on profitability. The inconsistency of the research results is indicated by the effect of the environmental management system as a measure of environmental performance on profitability. Research conducted by Ong et al., (2016) and Septiandi et al., (2016) prove that environmental performance has a significant positive effect on profitability. A different thing showed by research conducted by Ningtyas \& Triyanto (2019) which in fact shows that there is no effect of environmental performance on profitability.

Research conducted by Ilaboya \& Ohiokha (2016) and Hui et al., (2013) prove that company age has a significant positive effect on profitability, whereas Yazdanfar \& Öhman (2016) and Yazdanfar \& Öhman (2014) show a significant negative result, and
Novyanny \& Turangan (2017) and Hariyanto \& Juniarti (2014) show that there is no effect of company age on profitability. The inconsistency of the research results is indicated by the effect of the company size variable on profitability. Research conducted by Yazdanfar \& Öhman (2016) and Yazdanfar \& Öhman (2014) prove that company size has a significant positive effect on profitability. A different thing shown by the research of Hariyanto \& Juniarti (2014) which shows a significant negative effect of company size on profitability, whereas Niresh \& Velnampy (2014) and Ratnasari \& Budiyanto (2016) in fact, show that company size has no effect on profitability.

The appearance of some inconsistencies in the results of these studies is assumed due to several independent variables that have not been used in one model. In this study, environmental disclosure, environmental performance, company age, and company size are examined for their effect on profitability in one model. The renewal of this study is indicated by the addition of the variables of company age and company size. In the previous research, these variables have never been examined for their effect on profitability in one model, including together with environmental disclosure and environmental performance variables. Not only that, this study also uses content analysis based on the GRI Standards 2016 in measuring environmental disclosure so that it is better able to measure environmental disclosure items in detail. Meanwhile, environmental performance is measured using the presence or absence of ISO 14001 certification, which is an international environmental management certification.

The purpose of this study is to obtain empirical evidence from testing the effect of environmental disclosure, environmental performance, company age, and company size on profitability in the companies listed in SET 100 Thailand in 2018.

\section{Literature Review \\ 2.1. Signalling Theory}

This research uses signalling theory as a grand theory. Brigham \& Houston (2013) explained that signal is an action taken by company management as a hint for investors regarding company prospects in the future. All of these actions contain various information about the company which arises because of the asymmetry of information between stakeholders and management. Management knows more information than stakeholders since management is directly involved in company activities whereas stakeholders do not. This underlies management to send certain signals or signs to stakeholders related to the actual condition of the company, in the hope that stakeholders can find out the condition of the company.

A qualified company will strive to send information to stakeholders in the form of a signal or code indicating that the company's performance is optimal. The signalling becomes the basis for 
stakeholders' assumption that they are not wrong in choosing the investment decision and that potential stakeholders will be interested in investing in the company. Profitability is the most important factor highlighted by stakeholders when making investment decisions. High profitability reflects optimal financial performance so that stakeholders are able to obtain maximum returns.

\subsection{Hypothesis Formulation}

The wide or not environmental disclosure will greatly affect the company's image in the eyes of stakeholders. Stakeholders' trust in company performance is directly proportional to the extent of environmental disclosure. Through the efforts of environmental disclosure done by companies, stakeholders will consider the companies as a party that really pays attention to environmental sustainability in carrying out its operational activities. Not only that, environmental disclosure activities that are carried out transparently and sustainably will make it easier for the companies to gain trust from the public. This trust determines the survival of the company which also affects the achievement of profitability in a certain period. In accordance with the signal theory, this will have an impact on providing signals to stakeholders that is related to the achievement of profitability which will later affect stakeholders' interest in investing. This framework of thinking is supported by research conducted by Ningtyas \& Triyanto (2019), Che-Ahmad \& Osazuwa (2015), and Nurleli \& Faisal (2017) which prove that there is a significant effect of environmental disclosure on profitability.

$\mathrm{H}_{1}$ : Environmental disclosure has a significant effect on profitability

The signal theory explains that corporate operational activities will later be shared with stakeholders by management in the form of certain signals including profitability signals, which can influence stakeholder investment decisions. One of the factors that influences profitability is environmental performance. The quality of environmental performance is a reflection of the company's ability to carry out environmental management. The existence of ISO 14001 certification in a company indicates that the company has been able to meet the environmental management requirements according to the standards. This will affect public trust in the company. The form of trust is often carried out by supporting company activities through recognition of the existence and use of products that the company produces over a long period of time. This condition will affect the company's revenue which is then accumulated in the form of profitability achievements. Information related to profitability is a very useful signal for stakeholders to make investment decisions in the company. This statement is in accordance with the results of research conducted by Ong et al., (2016) and (Septiandi et al., 2016) which reveal that there is a 68 significant effect of environmental performance on profitability.

$\mathrm{H}_{2}$ : Environmental performance has a significant effect on profitability

The age of a company greatly determines the company's ability to manage its business activities. The ability to survive in facing obstacles and competition is certainly influenced by age factor. Company age also determines the company's experience in carrying out business activities, especially in terms of achieving profitability. Stable operational activities will certainly bring many benefits, one of which is the opportunity to create higher profitability. In accordance with the signal theory, profitability is a key indicator highlighted by stakeholders. The achievement of profitability triggers the intensity of stakeholders' interest to invest. Research conducted by Ilaboya \& Ohiokha (2016), Hui et al., (2013), Yazdanfar \& Öhman (2016), and Yazdanfar \& Öhman (2014) show that there is a significant effect of company age on profitability.

$\mathrm{H}_{3}$ : Company age has a significant effect on profitability

Company size becomes one of the reflections of the complexity level of the operational activities of a company. Complex activities indirectly affect profitability that will be generated by the company. Profitability plays an important role in gaining trust from investors. In accordance with the signal theory, profitability becomes the main signal for stakeholders, which can influence stakeholders' interest in investing in a company. Company size can also be an indication that the company has been able to survive and tends to be stable in managing its operational activities and the existence has been recognized by stakeholders. This statement is supported by the research conducted by Yazdanfar \& Öhman (2016), Yazdanfar \& Öhman (2014), and Hariyanto \& Juniarti (2014) which prove that company size has a significant effect on profitability.

$\mathrm{H}_{4}$ : Company size has a significant effect on profitability

\section{Research Method}

This study used a quantitative approach with a hypothesis testing study design. A total of 100 companies listed on the Stock Exchange of Thailand were the population in this study. This study used an observation period in 2018. The criteria for determining the sample were selected by purposive sampling technique and obtained as many as 85 companies as samples. The sample selection criteria can be seen in Table 1 .

This study determined profitability as the dependent variable and the variables of company age, company size, environmental performance, and environmental disclosure as the independent variables. The operationalization and measurement of the research variables are presented in Table 2. 
The data in this study were secondary data with documentation techniques as data collection techniques. The research data were obtained from financial reports and/or sustainability reports and/or company websites that have been officially published on the website www.set.th and the respective companies' websites.

Table 1. Sample Determination Criteria

\begin{tabular}{clc}
\hline \hline No & \multicolumn{1}{c}{ Criteria } & Total \\
\hline 1. & Companies listed on SET100 Thailand in 2018 & 100 \\
2. & Thailand Companies with Thai language & $(4)$ \\
& environmental disclosure media & \\
3. Companies with an annual reporting period & $(6)$ \\
& not on January 1 - December 31, 2018 & \\
4. Companies that incurred losses during 2018 & $(5)$ \\
Total final samples & 85 \\
The final total of analysis units & 85 \\
\hline \multicolumn{2}{l}{ Source: Secondary Data Processed by the Year 2020 }
\end{tabular}

Table 2. Operational Definition of the Variables

\begin{tabular}{|c|c|c|}
\hline Variables & Definition & Measurement \\
\hline $\begin{array}{l}\text { Profitability } \\
\text { (PROF) }\end{array}$ & $\begin{array}{l}\text { The company's ability to } \\
\text { make profits } \\
\text { (Risdawaty \& Subowo, } \\
\text { 2015) }\end{array}$ & $\begin{array}{l}\text { Return On Equity } \\
=\frac{\text { Net Profit After Tax }}{\text { total equities }} \times \\
100 \% \\
\text { (Gatimbu \& } \\
\text { Wabwire, 2016) }\end{array}$ \\
\hline $\begin{array}{l}\text { Company Age } \\
\text { (AGE) }\end{array}$ & $\begin{array}{l}\text { Company age from } \\
\text { listing date to } 31 \\
\text { December } 2018 \\
\text { (D'Amico et al., 2014). }\end{array}$ & $\begin{array}{l}=\mathrm{LN} \text { (total } \\
\text { months) }\end{array}$ \\
\hline $\begin{array}{l}\text { Company Size } \\
\text { (SIZE) }\end{array}$ & $\begin{array}{l}\text { Size regarding the small } \\
\text { or large of a company } \\
\text { (Irawati, 2012). }\end{array}$ & 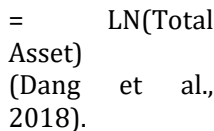 \\
\hline $\begin{array}{l}\text { Environmental } \\
\text { Performance } \\
\text { (EMS) }\end{array}$ & $\begin{array}{l}\text { The processes and } \\
\text { practices that enable an } \\
\text { organization to reduce } \\
\text { its environmental impact } \\
\text { and increase the } \\
\text { efficiency of its } \\
\text { operations } \\
\text { (Environmental } \\
\text { Protection Agency, } \\
\text { 2017) }\end{array}$ & $\begin{array}{l}\text { The EMS used in } \\
\text { this study uses a } \\
\text { proxy for the } \\
\text { presence or } \\
\text { absence of ISO } \\
14001 \\
\text { certification. } \\
1=\text { if have EMS } \\
0=\text { if not have } \\
\text { EMS } \\
\text { (Chaklader \& } \\
\text { Gulati, 2015) }\end{array}$ \\
\hline $\begin{array}{l}\text { Environmental } \\
\text { disclosures } \\
\text { (ED) }\end{array}$ & $\begin{array}{l}\text { The company's efforts in } \\
\text { disclosing } \\
\text { environmental } \\
\text { information } \\
\text { (Wahyuningrum \& } \\
\text { Budihardjo, 2018). }\end{array}$ & $\begin{array}{l}\text { Content analysis: } \\
\text { Score 1: one } \\
\text { sentence } \\
\text { Score 2: one } \\
\text { paragraph } \\
\text { Score 3: half of } \\
\text { A4 page } \\
\text { Score 4: one A4 } \\
\text { page } \\
\text { Score 5: more } \\
\text { than one A4 page } \\
\text { (Raar, 2002). }\end{array}$ \\
\hline
\end{tabular}

Several statistical analyzes were carried out in this study, including descriptive statistical analysis, classical assumptions, and multiple linear regression. In order to obtain a general description of the data such as minimum, maximum, mean, and standard deviation values, this study conducted a descriptive statistical analysis. Before the multiple linear regression analysis was carried out in order to prove that the research model was an estimation model that was free from bias, this study conducted a classical assumption test which included multicollinearity test, autocorrelation test, normality test, and linearity test. The research model was a multiple linear regression model shown by equation 1 . Furthermore, by using a significance level of $5 \%$, this study determined whether to accept or reject the hypothesis proposed. $\mathrm{ROE}=\alpha+\beta 1 \mathrm{AGE}+\beta 2 \mathrm{SIZE}+\beta 3 \mathrm{EMS}+\beta 4 \mathrm{ED}$

\section{Results and Discussion}

This study uses descriptive statistical and inferential statistical tests. Descriptive statistical test is conducted to determine the distribution of data from the dependent variable and the independent variable. The results of the descriptive statistical test conducted using IBM SPSS Statistics version 26 can be seen in table 3.

Table 3. Descriptive Statistics Test Results

\begin{tabular}{lccccc}
\hline \hline & N & Minimum & Maximum & Mean & $\begin{array}{c}\text { Std. } \\
\text { Deviation }\end{array}$ \\
\hline PROF & 85 & $-7,70$ & 51,90 & 13,21 & 10,10 \\
AGE & 85 & 3,00 & 6,26 & 5,11 &, 96 \\
SIZE & 85 & 17,27 & 28,73 & 24,39 & 1,82 \\
EMS & 85 & 0 & 1 &, 34 &, 48 \\
ED & 85 & 0 & 53 & 11,41 & 10,90 \\
Valid N & 85 & & & & \\
(listwise) & & \multicolumn{5}{l}{} \\
Source: IBM SPSS Statistic version 26 data processed (2020)
\end{tabular}

Based on table 3, it can be seen that there are still several companies in Thailand that have not disclosed environmental responsibility in accordance with government regulations. This is evidenced by the minimum value of the environmental disclosure variable with a value of 0 . Meanwhile, the highest value of environmental disclosure is 53 items. Then, the disclosure of social responsibility in Thailand is also classified as low with an average value of 11,41.

The classical assumption test in this study includes residual normality, autocorrelation, multicollinearity, and heteroscedasticity tests before conducting multiple linear regression models and hypotheses testing. Based on the One-Sample Kolmogorov-Smirnov test which is a test to examine the distribution of residual data, it can be concluded that the research data is normally distributed because the test obtains a value of 0,081 with a significance level of 0,601 . Based on the durbin-watson test which is a test to examine for period interfering errors in periods $t$ and $t-1$, it can be concluded that there is no positive and negative autocorrelation $(\mathrm{du}<\mathrm{d}<4-\mathrm{du})$ since the value of $d$ is obtained for 1.698 and du of 1.525. The result of the tolerance value calculation, which is a multicollinearity test, shows that none independent variable has a tolerance value less than 0,10 , which means that there is no correlation between the independent variables with a value of more than 95\%. The Glejser test, which is a heteroscedasticity test, shows that there are no independent variables which statistically significantly 
affect the dependent variable. The value of Adjusted R2 obtained from multiple linear regression test of 0,150 , shows that the independent variables in this research model can explain the dependent variable by $15 \%$, while the other $85 \%$ is explained by other variables outside the research model.

Based on the results of the classical assumption test above, it can be concluded that the research model gives the Best Linear Unbiased Estimator (BLUE) result. Then, the estimation result from the research model is shown by equation 2 .

$\mathrm{ROE}=62.938+0.267-0.267 \mathrm{ED}+5.132 \mathrm{EMS}-$ 1.065 Age + 2.314 Size

A summary of the results of the individual parameter significance test (t-test) can be seen in Table 4.

Table 4. The Conclusion on Hypothesis Testing

\begin{tabular}{|c|c|c|c|c|}
\hline & Hypothesis & $\beta$ & Sig & Conclusion \\
\hline H1 & Environmental & 0.267 & 0.016 & accepted \\
\hline & $\begin{array}{l}\text { Disclosure (X1) has a } \\
\text { significant effect on } \\
\text { profitability }\end{array}$ & & & \\
\hline $\mathrm{H} 2$ & $\begin{array}{l}\text { Environmental } \\
\text { performance (X2) has a } \\
\text { significant effect on } \\
\text { profitability }\end{array}$ & $\begin{array}{c}- \\
5.132\end{array}$ & 0.035 & accepted \\
\hline $\mathrm{H} 3$ & $\begin{array}{l}\text { Company age (X3) has a } \\
\text { significant effect on } \\
\text { profitability }\end{array}$ & 1.065 & 0.372 & rejected \\
\hline $\mathrm{H} 4$ & $\begin{array}{l}\text { Company size (X4) has a } \\
\text { significant effect on } \\
\text { profitability }\end{array}$ & $\begin{array}{c}- \\
2.314\end{array}$ & 0.000 & accepted \\
\hline
\end{tabular}

\subsection{Environmental and Profitability Disclosures}

Environmental disclosure becomes one of the significant factors affecting profitability. This is evidenced by the test results that have been carried out which show that environmental disclosure has a significant effect on profitability in a positive direction so that $\mathrm{H}_{1}$ is accepted. This condition proves that the wider environmental disclosure will be able to increase the company's profitability. The extent of environmental disclosure triggers increased stakeholder trust towards company performance. The stakeholders will see the companies as a party that really pays attention to environmental sustainability in carrying out its operational activities. This will indirectly increase the purchasing power of customers on an ongoing basis for the products of the company. The increase in sales certainly has an effect on increasing the company's profitability. In accordance with the signal theory, this will have a positive impact on giving signals to stakeholders, that during that period the company's profitability is high and triggers the interest of stakeholders to invest. This research is in line with the research conducted by Ningtyas \& Triyanto (2019), Che-Ahmad \& Osazuwa (2015), and Nurleli \& Faisal (2017) which prove that there is a significant positive effect of environmental disclosure on profitability.

\subsection{Environmental Performance and Profitability}

Based on the test results, it is known that environmental performance is proven to have a significant effect on profitability so that $\mathrm{H} 2$ is accepted. The direction of this effect is negative, which means that the existence of ISO 14001 certification in a company can reduce the achievement of profitability and conversely. This is because in order to obtain ISO 14001 certification, the company requires a lot of costs, both administrative costs, or costs to carry out environmental management in accordance with the standards. The overall cost required, certainly, reduces the company's total profitability in a certain period. On the other hand, companies that are not ISO 14001 certified do not spend a lot of money on certification so they do not reduce their profitability. The results of this study have not been able be in line with signal theory, which states that management will provide signals to stakeholders, including profitability, for investment purposes. Referring to the signal theory, companies with ISO 14001 certifications are assumed to get more recognition so that stakeholders are more interested in investing. The negative relationship that arises in this study is the opposite of this statement.

\subsection{Company Age and Profitability}

Based on the research results, it is known that there is no significant effect between company age and profitability so that $\mathrm{H} 3$ is rejected. As many as $47,1 \%$ of sample companies are in the very high age category significantly. However, this is not able to affect profitability. This condition is since companies tend to remain oriented towards profitability, even though they are relatively young. Company age does not affect the level of profitability, because, in this modern era, companies can gather a lot of knowledge about how to manage a company through existing technological sophistication, without having to wait long.

This finding also indicates that the sample companies have a high profitability orientation so that even though around $38 \%$ are very young to moderate in age, they still manage to enter the SET100 index, which is one of the largest capitalization indexes in SET in 2018. This is also supported by one of the rules issued by SET regarding special requirements that must be met in order for a company to be included in the SET100 index, namely the monthly turnover of company shares must be more than $50 \%$ of the total average monthly turnover value per common share in the same month (The Stock Exchange of Thailand, 2013). This indicates that the stock turnover in the sample companies is higher than other companies, where this turnover is one of the determinants of the profitability level in a company.

The results have not been able to prove the content of the signal theory, which implies that company age which is getting older can increase profitability, which is a good signal for stakeholders. This research is in line with the research conducted by Novyanny \& Turangan (2017) and Hariyanto \& 
Juniarti (2014), which prove that there is no significant effect between company age and profitability.

\subsection{Company Size and Profitability}

Company size is proven to have a significant effect on profitability so that $\mathrm{H} 4$ is accepted. The direction of effect on this relationship is significant negative, which means that larger company size will reduce the amount of profitability and conversely. This condition is not in line with the summary of the signal theory content that management provides signals to stakeholders regarding the information in the company in order to reduce information asymmetry that occurs. The significant negative effect of company size on profitability is due to the greater the size of a company, the greater the complexity of the bureaucracy which has the potential to cause information asymmetry between management and stakeholders (De Miguel, Pindado, \& De La Torre, 2004). This research is in line with the research result of Hariyanto \& Juniarti (2014) which proves that there is a significant negative effect of company size on profitability.

\section{Conclusions}

This study aims to examine empirically the effect of environmental disclosure, company age, company size, and environmental sustainability on profitability. The wider environmental disclosure is expected to be able to increase the achievement of profitability. However, company age is not a factor affecting profitability in this study. Meanwhile, the environmental performance as measured by the existence of ISO 14001 certification, as well as the increasing size of the company are proven to be able to reduce corporate profitability. This condition is since ISO 14001 certification requires a lot of costs and company size which is getting bigger creates bureaucratic complexity so that it has an impact on reducing the company's profitability.

A recommendation that can be given in accordance with the findings of this study is the use of other media by companies in making environmental disclosures. In order to increase the achievement of profitability, companies are advised to be able to expand their environmental disclosure by optimizing existing media, one of which is via website, which is in line with the current era of digitalization. In addition, the decrease in profitability due to ISO 14001 certification can be minimized with the role of the government as a regulator, which is expected to be able to control the costs of processing ISO 14001. The complexity of the bureaucracy that reduces profitability can be trimmed by the existence of regulations from the local government. It is recommended for further research to use the GRI standards 2016 which came into effect on July 1, 2018, to measure the quantity of environmental disclosure. This research was conducted in the transitional period so that there are still some companies that have not used GRI Standards in their environmental disclosures. This research has not used the GRI standards 2018, as the research period is still included in the transition period of the rules. Therefore, it is expected that further research can be carried out using the period time after this regulation applies so that there will be uniformity in environmental disclosure by all companies listed in Thailand.

\section{REFERENCES}

Alarussi, A. S., and Alhaderi, S. M. 2018. Factors affecting profitability in Malaysia. Journal of Economic Studies, Vol. 45 No. 3. Pages 442-458.

BBC Indonesia. 2019. Bangkok: Kabut Asap Beracun, Ratusan Sekolah Thailand Ditutup.

Brigham, E. F., and Houston, J. F. 2013. Fundamentals of Financial Management Eleventh Edition (8th ed.). USA: Cengage Learning.

CFA Institute. 2019. ESG Disclosures in Asia Pacific.

Chaklader, B., and Gulati, P. A. 2015. A Study of Corporate Environmental Disclosure Practices of Companies Doing Business in India. Global Business Review, Vol. 16 No. 2. Pages 321-335.

Che-Ahmad, A., and Osazuwa, N. P. 2015. Environmental Accounting and Firm Profitability in Nigeria: Do firm specific effects matter? The IUP Journal of Accounting Research \& Audit Practices, Vol. XIV No. 1. Pages 4354.

Christiastuti, N. 2018. Polusi Udara di Bangkok Berbahaya, Anak-Anak Dilarang Keluar.

D’Amico, E., Coluccia, D., Fontana, S., and Solimene, S. 2014. Factors Influencing Corporate Environmental Disclosure. Business Strategy and the Environment, Vol. 25 No. 3. Pages 178-192.

Dang, C., (Frank) Li, Z., and Yang, C. 2018. Measuring Firm Size in Empirical Corporate Finance. Journal of Banking and Finance, Vol. 86. Pages 159-176.

De Miguel, A., Pindado, J., and De La Torre, C. 2004. Ownership Structure and Firm Value: New evidence from Spain. Strategic Management Journal, Vol. 25 No. 12. Pages 1199-1207.

Environmental Protection Agency. 2017. Environmental Management Systems (EMS).

Gatimbu, K. K., and Wabwire, J. M. 2016. Effect of Corporate Environmental Disclosure on Financial Performance of Firms Listed at Nairobi Securities Exchange. Kenya. International Journal of Sustainability Management and Information Technologies, Vol. 2 No. 1. Pages 1-6.

Hariyanto, L., and Juniarti. 2014. Pengaruh Family Control, Firm Risk, Firm Size Dan Firm Age Terhadap Profitabilitas Dan Nilai Perusahaan Pada Sektor Keuangan. Business Accounting Review, Vol. 2 No. 1. Pages 141-150.

Hui, H., Wan Mohamed Radzi, C., Jenatabadi, H., Abu Kasim, F., and Radu, S. 2013. The Impact of Firm Age and Size on the Relationship Among Organizational Innovation, Learning, and Performance: A Moderation Analysis in Asian Food Manufacturing Companies. Interdisciplinary Journal of Contemporary Research in Business, Vol. 5 No. 3.

Ilaboya, O. J., and Ohiokha, I. F. 2016. Firm Age, Size and Profitability Dynamics: A Test of Learning by Doing and Structural Inertia Hypotheses. Business and Management Research, Vol. 5 No. 1.

Irawati, D. E. 2012. Pengaruh Struktur Modal, Pertumbuhan Laba, Ukuran Perusa- Haan Dan Likuiditas Terhadap 
Kualitas Laba. Accounting Analysis Journal, Vol. 3 No. 1. Hal. 361-369.

Khidir, S. 2019. Thailand's New Leader Must Fix the Environment.

Ningtyas, A. A., dan Triyanto, D. N. 2019. Pengaruh Kinerja Lingkungan dan Pengungkapan Lingkungan Terhadap Profitabilitas Perusahaan. Jurnal Akuntansi, Audit Dan Sistem Informasi Akuntans, Vol. 3 No. 1. Hal. 14-26.

Niresh, J. A., and Velnampy, T. 2014. Firm Size and Profitability: A Study of Listed Manufacturing Firms ed Manufacturing Firms in Sri Lanka. International Journal of Business and Management, Vol. 9 No. 4. Pages 57-64.

Nor, N. M., Bahari, N. A. S., Adnan, N. A., Kamal, S. M. Q. A. S., and Ali, I. M. 2016. The Effects of Environmental Disclosure on Financial Performance in Malaysia. Procedia Economics and Finance, Vol. 35. Pages 117126.

Novyanny, M. C., dan Turangan, J. A. 2017. Pengaruh Likuiditas, Ukuran Perusahaan, Umur Perusahaan dan Pertumbuhan Perusahaan Terhadap Profitabilitas Pada Perusahaan Jasa Terdaftar Pada Bursa Efek Indonesia. Journal of Management Studies, Vol. 4 No. 1. Hal. 66-78.

Nurleli, dan Faisal. 2017. Pengaruh Pengungkapan Informasi Lingkungan Terhadap Kinerja Keuangan. Kajian Akuntansi, Vol. 16 No. 1. Hal. 31-54.

Ong, T. S., Teh, B. H., Ng, S. H., and Soh, W. N. 2016. Environmental Management System and Financial Performance. Institutions and Economies, Vol. 8 No. 2. Pages 26-52.

Raar, J. 2002. Environmental initiatives: Towards triplebottom line reporting. Corporate Communications: An International Journal, Vol. 7 No. 3. Pages 169-183.

Ratnasari, L., dan Budiyanto. 2016. Pengaruh Leverage, Likuiditas, Ukuran Perusahaan terhadap Profitabilitas pada Perusahaan Otomotif di BEI. Ilmu dan Riset Manajemen, Vol. 5 No. 6. Hal. 1-15.
Risdawaty, I. M. E., dan Subowo. 2015. Pengaruh Struktur Modal, Ukuran Perusahaan, Asimetri Informasi, dan Profitabilitas terhadap Kualitas Laba. Jurnal Dinamika Akuntansi, Vol. 7 No. 2. Hal. 109-118.

Septiandi, K., Lestari, R., dan Nurleli. 2016. Pengaruh Penerapan Sistem Manajemen Lingkungan (SML) ISO 14001 terhadap Tingkat Profitabilitas Perusahaan Manufaktur Khususnya Subsektor Industri Dasar dan Kimia di Indonesia yang Listing di BEI Tahun 20142015. Prosiding Akuntansi, Hal. 628-635.

Sulistiawati, E., and Dirgantari, N. 2017. Analisis Pengaruh Penerapan Green Accounting Terhadap Profitabilitas Pada Perusahaan Pertambangan Yang Terdaftar Di Bursa Efek Indonesia. Jurnal Reviu Akuntansi Dan Keuangan, Vol. 6 No. 1. Hal. 865-872.

The Stock Exchange of Thailand. SET50 and SET100 Indices Rule. 2013. Thailand.

Wahyuningrum, I. F. S., and Budihardjo, M. A. 2018. Relationship between Company Financial Performance, Characteristic and Environmental Disclosure of ASX Listed Companies. E3S Web of Conferences, Vol. 73. Pages 3-7.

Yanto, H., and Muzzammil, B. S. 2016. A Long Way to Implement Environmental Reporting in Indonesian Mining Companies. International Journal of Applied Business and Economic Research, Vol. 14 No. 10. Pages 6493-6513.

Yazdanfar, D., and Öhman, P. 2014. The Impact of Cash Conversion Cycle on Firm Profitability: An Empirical Study Based on Swedish Data. International Journal of Managerial Finance, Vol. 10 No. 4. Pages 442-452.

Yazdanfar, D., and Öhman, P. 2016. The Impact of Trade Credit Use on Firm Profitability: Empirical Evidence from Sweden. Journal Od Advances in Management Research, Vol. 13 No. 2. Page 19. 